THE MYTH OF MASS CULTURE 
Also by Alan Swingewood

MARX AND MODERN SOCIAL THEORY

THE NOVEL AND REVOLUTION 


\title{
The Myth of
}

\section{Mass Culture}

\section{ALAN SWINGEWOOD}

\author{
Lecturer in Sociology \\ London School of Economics and Political Science
}

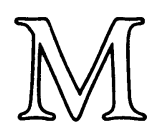


() Alan Swingewood 1977

Softcover reprint of the hardcover 1st edition 1977

All rights reserved. No part of this publication may be reproduced or transmitted, in any form or by any means, without permission.

\author{
First published 1977 by \\ THE MACMILLAN PRESS LTD \\ London and Basingstoke \\ Associated companies in New York Dublin \\ Melbourne Johannesburg and Madras
}

ISBN 978-0-333-21408-4 ISBN 978-1-349-15783-9 (eBook)

DOI 10.1007/978-1-349-15783-9

This book is sold subject to the standard conditions of the Net Book Agreement.

The paperback edition of this book is sold subject to the condition that it shall not, by way of trade or otherwise, be lent, resold, hired out, or otherwise circulated without the publisher's prior consent in any form of binding or cover other than that in which it is published and without a similar condition including this condition being imposed on the subsequent purchaser. 


\section{Contents}

Introduction

vii

1 The Theory of Mass Society

1

Origins: de Tocqueville, Nietzsche, Gasset, T. S. Eliot and Leavis

Mass Society as Totalitarianism: Mills, Adorno,

Horkheimer, Marcuse and the 'Culture Industry'

Mass Society as Pluralistic Democracy: Shils, Bell and Post-Industrial Culture

2 Marxism and Culture

Culture, Technique and Production: Trotsky's Critique 24

Hegemony and the Theory of 'Incorporation'

Working-Class Culture, Bourgeois Hegemony,

Class Domination and Ideology: Hoggart and Williams 39

3 Fiction and 'Proletarian Culture'

Marxism and the Concept of Proletarian Culture:

Lenin and Trotsky

Culture and Class: the Transition from Mob to

Organised Labour

Robert Tressell: the Working Classes as Prisoners

of the System

Walter Greenwood and Grassic Gibbon: Reformism and Revolution

The Welfare State, Egalitarian Ideology and

Working-Class Culture: Braine, Sillitoe and Hines 66

The Myth of the Proletarian Novel

4 Ideology and Mass Communications - the

Problem of Legitimacy

The Capitalist State and Ideological Domination

Legitimation and the Concept of Public Sphere

Ideology and False Consciousness: Althusser and Poulantzas 
The Crisis of Bourgeois Legitimacy: Habermas and Bell

5 Mass Culture or Democratisation of Culture?

The Social Formation and the Concept of Cultural Levels

The Development of Capitalist Culture: Institutional Structure and the Threat from Below

The Dialectic of Modern Culture: the Political

Consequences of Literacy and Mass Consumption 105

Humanism, Socialism and Culture

Conclusion: Culture and Collectivism - Myth as

Domination

Notes and References

Select Bibliography

Index 


\section{Introduction}

This book has grown out of a much larger and more comprehensive study of the problems of class domination in modern capitalist societies and especially of the question of the role of the state in the maintenance of the capitalist mode of production. In recent years there has been a remarkable revival of interest in Marxist theory and Marxist schools of thought. The major trend has been to rediscover the works of Lukács, Korsch, Gramsci, Adorno, Marcuse, Horkheimer, Rosdolsky, Benjamin (most of whose major works were written during the 1920s and 1930s) and counterpose them to both Stalinism and Trotskyism. At the same time there has emerged a contemporary Marxism which, grouped round the theory of structuralism and the work of the French communist philosopher Louis Althusser, strives towards a scientific methodology and a rejection of the 'humanist' basis of these older Marxists. In general, both this rediscovered and contemporary Marxism are philosophical, epistemological and abstract in orientation rather than sociological, concrete and historical. It is this elimination of the historical dimension in Marxist social theory which is perhaps the most striking characteristic of these different writers (with the exception of Gramsci), and.in their analysis of modern capitalism they develop a static and pessimistic concept of the social formation. To understand these different Marxist traditions it becomes essential to relate them to the historical and political contexts, especially to the failure of proletarian revolutions in western Europe during the 1920s and 1930s and the totalitarian nature of Stalinism: by 1940, with the murder of Trotsky, all effective opposition to Stalinism within both the 
Russian Communist party and those parties outside Russia had been wiped out. Two fatal consequences resulted in the sphere of social theory and it is these which are examined in this book.

1. Marxist thought, which remained independent of the Stalinist Third International (1928 onwards), rejected the revolutionary role of the European working class, and in the work of the Frankfurt School (Adorno, Horkheimer, Marcuse, Kracauer, Lowenthal) the goal of socialism was transformed into mere utopia. Writing in the late 1920s and 1930s, during a period of titanic class struggles in Austria, Germany and France, the Frankfurt school argued that capitalism in Marx's terms was now an anachronism: massive state intervention in the market, the autonomous and reifying role of technology and science within the mode of production and administration, and the growth of a consumptionoriented working class had rendered the Marxist concept of class struggle obsolete. Modern capitalism was a mass society in which the proletariat constituted an atomised rather than an organised structure and was easily swayed by irrational ideologies such as fascism: in Western capitalism as well as in the Soviet Union the same processes were taking place, leading to a society of pliant and obedient masses. All independent and autonomous groups and individuals were either absorbed by the state or simply annihilated. In outline, therefore, the theory of mass society and mass culture identified with the Frankfurt school was worked out long before the Nazis sent their leading theorists into exile to America, where they developed a more sociological approach under the rubric of the 'culture industry'. Thus the working classes. were the prisoners not only of irrational psychology and ideological disposition (supporting 'authoritarian' political parties) but also of omnipresent forces of the capitalist mass media.

2. This totally pessimistic vision of the evolution of capitalism and socialism was closely linked with perhaps the greatest illusion of orthodox Marxist thought: the belief in the historical necessity of capitalist decline from a progressive high point in the mid-nineteenth century to its degeneration 
and virtual collapse by the 1920 s and 1930s. For the Frankfurt School, the decline of capitalism was shown by a progressive weakening of bourgeois authority and values leading to problems of legitimation; for the Stalinists and for Trotsky also, capitalism would inevitably collapse through the workings of certain economic and social laws and the activities of a disciplined revolutionary party. ${ }^{1}$ Capitalist culture and social relations must of necessity degenerate into barbarism or, revitalised by revolutionary praxis, form the basis of a socialist society. A theory of economic determinism and historical fatalism was thus characteristic of both the orthodox and the unorthodox Marxist analyses of culture: the forces and relations of capitalist production are brought into conflict and no further development is possible. Capitalist culture is therefore 'in decline', its social and ideological function to dupe the masses into false beliefs and bourgeois values. For many contemporary Marxists, the term 'late capitalism' implies that the historically necessary collapse of capitalism has been averted by the conscious ideological and cultural manipulation of the bourgeoisie over the proletariat. $^{2}$

It will be the argument of this book that capitalist economy and technology and capitalist culture, far from degenerating into 'barbaric meaninglessness' (Adorno and Horkheimer) and irreversible decline, have achieved new pinnacles of economic and cultural richness and diversity on a scale unparalleled in human history: as there is no 'final crisis' in capitalist economy so there is no final crisis in its culture. Far from it: the development of the capitalist mode of production has served to augment, not destroy, civil society. It has created a more complex and autonomous social structure in which the key institutions of trade unions, political parties, occupational associations and the communications and cultural media are not dominated by a massive and all-powerful state apparatus but exercise a greater mediating influence than was ever possible during the 'progressive' phase of capitalist evolution. Capitalism has succeeded in building up and strengthening the social relations of production and working-class organisations so much so that a far more delicate balance of forces is now capitalism's most 
characteristic feature. Yet for those Marxists working in the shadow of the Frankfurt School or a dogmatic Trotskyism, contemporary capitalism is a society in which a totalitarian state intervenes decisively in the management of economic affairs by controlling the independence of the labour movement through a mixture of welfare programmes and the involvement of trade unions in governmental administration. Such monolithic concepts of social structure, however, cut short the dialectical movement: of course the modern state grows in size and complexity, but as capitalism strengthens the sphere of direct domination so it necessarily creates the basis of a powerful civil society. For as a dominant class the bourgeoisie must subjugate the proletariat to its authority and confront the daily realities of class struggle through the repressive apparatus of a strong, centralised state; but equally the bourgeoisie seeks to dominate society through its own institutions built upon parliamentary democracy and a free market economy and thus achieves legitimation not through force but through consent. But this process of hegemony is never total: as civil society grows ever more resilient with the development of independent bourgeois institutions, working-class organisations and socialist ideology come to challenge bourgeois-class domination. The exercise of hegemony within the context of contemporary capitalism (which in sharp contrast to nineteenth-century European capitalisms has successfully eliminated residual feudal, non-capitalist and nonindustrial structures) has thus become centred on the mode of integration of the proletariat, especially in terms of politics and culture. This function of social integration (that is integration from above) is not carried out by the state: it is a process based on the complex relations between the private institutions of civil society, bourgeois ideology and working-class organisation and leadership.

It is not only the Marxists, however, who have argued for the collapse of civil society and thus cultural vitality: in the writings of literary critics such as T. S. Eliot and F. R. Leavis, a nostalgic longing for a pre-industrial, non-capitalist society functions as moral touchstone for their critique of modern industrial capitalism. For these writers, as with the Frankfurt school theorists, the bourgeoisie is incapable of creating cultural 
vitality: it is capable of creating only a pallid, mechanical 'life-denying' civilisation - society and its culture are in rapid decline. As will be argued in the first chapter, this particular theory of mass culture is based on a rejection of the capitalist mode of production as a revolutionary force which builds simultaneously the institutions of popular culture (such as mass media, journalism and publishing) and the material, technological foundations of a potentially democratic culture (such as libraries and educational facilities). In both the dogmatic Marxist and the literary/cultural theories of mass culture, the concept of culture itself is abstracted from the complex web of social relations within capitalism and transformed into a monolithic notion of 'culture as a whole'. Since in these theories both culture and society are disintegrating, the focus is entirely on this abstract notion of culture rather than on the specific determinations and the historically concrete forms of capitalist culture: the result is a crude 'consumptionist' theory of culture in which subjective judgement and moral evaluation dominate to the exclusion of scientific analysis.

In the third and final version of the mass culture theory examined in this book - cultural pluralism - the emphasis shifts almost entirely from questions of domination, legitimacy and cultural vitality to the more prosaic problems of who consumes 'what, where and how'. In this theory, culture becomes synonymous with that which exists at the level of everyday life and stratified consumption patterns; the broader question of the relation of culture to class domination and ideology disappears. The pluralistic theory of mass culture focuses on a non-problematic concept of social integration and takes for granted the question of legitimation. Culture thus becomes separated from ideology and the analysis of the values it expresses is never related to class and social structure.

All three theories are profoundly conservative in their social and political implications. A mass culture is not the same as a democratic culture for the institutions of the former must work against the democratic participation of the masses in political, economic and cultural activities at all levels of the social formation. Mass culture implies the existence of superior groups who take the important decisions on behalf of the others, an élite, or 
élites, who work for the people over the people. In this book I shall try to show the anti-democratic animus of these different theories all of which, in favouring a static, ideological concept of culture either rooted in or forced upon a largely passive mass, reject culture as praxis, a means of transforming the world through consciousness, action and values. 